\title{
Review of "Pastures of Change: Contemporary adaptations and transformations among nomadic pastoralists of Eastern Tibet" by Gillian G. Tan
}

\author{
Emily Woodhouse
}

\author{
Book details \\ Tan, G.G. \\ Pastures of Change: Contemporary Adaptations and Transformations among Nomadic Pastoralists of Eastern Tibet \\ Cham: Springer; 2018. \\ 200 pages \\ 978-3-319-76552-5
}

Keywords: Tibet, Pastoralism, Adaptation, Caterpillar fungus, China, Development, Buddhism

As with other rangelands around the world, the Tibetan Plateau is undergoing unprecedented changes that are having dramatic effects on pastoral life. This change and the ways in which Tibetans have adapted to it lie at the heart of Gillian Tan's book. Tan focuses specifically on eastern Tibet, an area which, although falling largely outside of the Tibetan Autonomous Region (or Xizang in Chinese), is distinctly Tibetan but with its own rich history and identity. Tibetan nomadic pastoralists have faced change for millennia, but over the last 30 years, the rate and scale have escalated as Chinese state policies have reduced mobility, while capitalist penetration has altered the rural economy. The book incorporates elements of Tan's ethnographic research (she is an anthropologist at Deakin University in Australia) into a synthesis of the literature, including a growing body of work by Tibetan scholars, and takes in a range of contemporary issues spanning economic, social and religious aspects of change.

After an introduction to the ethnographic setting and the theoretical perspective, Chapter 3 starts with perhaps

\footnotetext{
Correspondence: e.woodhouse@ucl.ac.uk
} University College London, London, UK the most obvious driver of change: Chinese government policies. Upon the liberalisation of China after Mao's death in 1976, interventions intensified in Tibetan areas. These culminated in the campaign to 'open up the west' (xibu da kaifa) which aimed to close economic disparities between the prosperous east coast and the western provinces. The impacts on pastoralists include the implementation of formal education, ecological protection and infrastructure schemes. Grazing restrictions and fencing have been expanded and a programme of ecological resettlement introduced with the aim of restoring degraded grasslands. Since 2009, the Nomad Settlement project has focused on the further intensification of pastoral production. Despite shifts in government policy, Tan highlights the continuity in the state's view of nomadic pastoralists as 'backward' and a technocratic approach to social change that ignores the interdependent and complex relationships between pastoralists and grasslands. Drawing upon political ecology scholarship, the chapter discusses how a form of 'environmentality' is enacted, whereby a narrative of environmental degradation and material improvements are used by the state to turn Tibetans into market-orientated, governable 
subjects. The chapter focuses at the scale of national policy, and whilst there is a convincing argument about the state discourse, there is a lack of attention to fieldlevel studies. We are given little insight into how these policies play out on the ground where there are other forms of authority present, notably religion in the form of local Buddhist monasteries and incarnate lamas whose teachings and ritual power may either contest or articulate with that of the Chinese state.

The scale of analysis shifts quite significantly in Chapter 4 to focus on Tan's fieldwork with the 'Star Foundation' a pseudonym for three North American development organisations working in eastern Tibet. Tan's research suggests that the organisation's emphasis on quantifiable indicators and targets ultimately disregards the lived experiences of local Tibetans who must mould their needs into the language and log frames of international development. Local communities wanted electricity, a school and a road, but these voiced needs did not fit the priorities of empowerment and environmental protection. Instead, discussions were steered towards the idea of a co-managed nature reserve which in turn did not align with the way pastoralists use or relate to the grasslands. It is a familiar story of raised expectations and hope giving way to disappointment and mistrust. In much the same way as the chapter on government, the analysis draws upon Foucauldian critiques such as by James Ferguson (1994) who argues that development discourse serves to reinforce unequal power relations. In this way, Tan argues that parallels exist between the government and development organisations' approach to Tibetan communities. But she highlights an interesting tension in that the development organisation requires communities to be at once underdeveloped but also holds a belief that Tibetan culture is threatened so that change becomes 'an attempt to hold on to a certain way of life or way of being'. It is easy to read this chapter as a critique of development in its entirety, whilst forgetting that the industry is not monolithic, nor is it likely to be in its engagements with Tibetan communities. As Tan suggests in other parts of the book, Tibetans are active agents in processes of change, yet the question of how Tibetans may be mobilising or reshaping exocitized and static external representations of themselves to political or economic ends is not addressed. Emily Yeh (2014), for example, has written about how Tibetans have themselves led development projects, collaborating with both western and Chinese environmentalists.

The book moves in Chapter 7 to engagements with the market economy on the Tibetan Plateau through the trade in caterpillar fungus (Ophiocordyceps sinensis). Although there has been a long history of trade in the fungus as a medicinal product, it has become highly coveted as a gift by Chinese consumers and the price has sky-rocketed over the last 30 years. Tan rightly devotes a whole chapter to the fungus, and tells a compelling story about how in the creation of commodity value, inequality is increasing, new trade relationships are emerging, and ritual and moral relationships with nature are shifting.

Tan spends considerable time on the theoretical perspective of change which is centred on relationships rather than on single variables in order to contrast adaptations with transformations. In this perspective, adaptations constitute shifts in variables that do not alter functional relationships, whilst transformations do alter relationships. Importantly, Tan also argues that transformations include changes in values and cultural categories, for example, the increasingly commodified value of caterpillar fungus. This distinction proves useful in highlighting Tibetans as active participants in rather than victims of change, and the way in which some changes may be so fundamental as to be a threat to the viability of a recognisable form of nomadic pastoralism. The framing has echoes of resilience thinking (the final paragraphs acknowledge this), and in the last passages of the book, Tan describes dynamic relationships between humans and non-humans in a way that is very much akin to the idea of complex social-ecological systems. As a social anthropologist, Tan understandably focuses on social systems, but ecology, in my view, is underemphasised in the book and little of the current evidence on rangeland dynamics and degradation is featured. Climate change is not mentioned at all. This downplays the ways in which social systems are inextricably linked to the biophysical dynamics of grasslands and the importance of interdisciplinary perspectives in research and policy on the governance of rangelands.

A concerted attempt to apply the theoretical lens comes in Chapter 6 when Tan uses her experience in one community in Kham to examine processes of adaptation and transformation focusing on human relationships with animals, with each other and with territorial deities. Here, we are provided with more of a sense of local variation and how Tibetans are taking control of processes of change or resisting it, for example, by using settled housing provided by the government as storage or rejecting available funding entirely. There are glimpses of fascinating interactions between the economic, religious and ecological realms, for example, in people's changing relationships with yaks. The increasing commodification of animals and therefore slaughtering rates are countered by a growing Buddhist vegetarian movement and greater numbers of ritually liberated animals, the latter of which contributes to the reduction of productive yaks on the grasslands. The mentions of the vegetarian movement and the description of a school built by an incarnate lama suggest the centrality of religious authority in processes of change, but religion takes a somewhat peripheral role in the narrative which does 
not seem to fully reflect its importance in Tibetan society.

This is an ambitious book that covers some fascinating topics to illustrate the extent and complexities of change occurring among Tibetan pastoralists. The scope of a book that looks at multiple dimensions of change across a vast region means that not all aspects will receive the same attention. But overall, the balance feels too weighted towards the discourses of development (by international organisations and national government), over the religious and ecological dimensions of change and the experiences of Tibetans on the ground. The lack of ethnographic richness is perplexing given Tan is a social anthropologist and her previous book (In the Circle of White Stones, 2016) foregrounds the everyday lives of Tibetans very well. Nonetheless, Pastures of Change serves as a credible introduction to contemporary pastoralist life in eastern Tibet. As such, it will be of great interest and value to students, researchers and practitioners working in this pastoral region and beyond.

\section{Acknowledgements}

Not applicable

\section{Author's contributions}

EW wrote the manuscript with no other contribution. The author read and approved the final manuscript.

\section{Author's information}

None

\section{Funding}

The author did not receive any funding for this publication.

Availability of data and materials

Not applicable

Ethics approval and consent to participate

Not applicable

Consent for publication

Not applicable

Competing interests

The author declares that she has no competing interests.

Received: 2 April 2020 Accepted: 15 April 2020

Published online: 17 July 2020

\section{References}

Ferguson, J. 1994. The anti-politics machine: 'Development', depoliticization and bureaucratic power in Lesotho. Cambridge: Cambridge University Press.

Yeh, E.T. 2014. The rise and fall of the Green Tibetan: Contingent collaborations and the vicissitudes of harmony. In Mapping Shangrila: Contested landscapes in the Sino-Tibetan borderlands, ed. E.T. Yeh and C. Coggins, 255-278. Seattle: University of Washington Press.

\section{Publisher's Note}

Springer Nature remains neutral with regard to jurisdictional claims in published maps and institutional affiliations.

\section{Submit your manuscript to a SpringerOpen ${ }^{\circ}$ journal and benefit from:}

- Convenient online submission

- Rigorous peer review

- Open access: articles freely available online

- High visibility within the field

- Retaining the copyright to your article

Submit your next manuscript at $\boldsymbol{\nabla}$ springeropen.com 